\title{
Inoculum Density on Heterodera glycines Development in Resistant and Susceptible Soybean Cultivars
}

\author{
Fernando Godinho de Araújo ${ }^{1}$, Juliana de Oliveira Silva ${ }^{2}$, Kássia Aparecida Garcia Barbosa ${ }^{3}$, \\ Janaina Alves de Almeida Moreira ${ }^{2}$ \& Mara Rúbia da Rocha ${ }^{2}$ \\ ${ }^{1}$ Instituto Federal Goiano, Campus Urutaí, Urutaí, GO, Brazil \\ ${ }^{2}$ Escola de Agronomia, Universidade Federal de Goiás, Campus Samambaia, Goiânia, GO, Brazil \\ ${ }^{3}$ Faculdade de Fisiologia e Ciências Humanas de Goiatuba, Goiatuba, GO, Brazil \\ Correspondence: Fernando Godinho de Araújo, Instituto Federal Goiano, Campus Urutaí, Rodovia Geraldo Silva \\ do Nascimento, Km 2.5, CEP: 75790-000. Urutaí, GO, Brazil. Tel: 55-643-465-1973. E-mail: \\ godinhoaraujo@hotmail.com
}

Received: September 21, 2018

Accepted: November 7, $2018 \quad$ Online Published: January 15, 2019

doi:10.5539/jas.v11n2p499

URL: https://doi.org/10.5539/jas.v11n2p499

\begin{abstract}
A series of factors can affect populations of $H$. glycines and even its life cycle, including inoculum density and genetic resistance of soybean cultivars. This study evaluated whether resistance reaction to $H$. glycines is effective in reducing nematode development under high inoculum concentration, as well as if such resistance reaction and inoculum density affect juvenil penetration and survival rate of $H$. glycines. Two trials were done using three soybean cultivars: one susceptible (BRS Valiosa RR) and two resistant (BRSGO Chapadões and BRSGO 8860RR) to $H$. glycines. The cultivars were subjected to four inoculum density $(1,000,2,500,5,000$ and 10,000 eggs and $\mathrm{J} 2$ per pot). The experimental design was completely randomized, in a $3 \times 4$ factorial scheme, with twelve replications. Two evaluations were done at 10 and 30 days after inoculation (DAI). Juvenile penetration in the roots was evaluated at 10 DAI and the number of females in the roots was estimated at 30 DAI. The survival rate was determined using both evaluations. Increasing initial density of $H$. glycines inoculum resulted in the increase of nematode final population in the susceptible cultivar, and the resistance reaction of soybean cultivars was not affected by the inoculum concentration. Penetration of $\mathrm{J} 2$ in the roots increased as inoculum density increased regardless of cultivar resistance or susceptibility. Nematode survival rate was greater in the susceptible cultivar.
\end{abstract}

Keywords: cyst nematode, Glycine max, survival rate

\section{Introduction}

Soybean cyst nematode (Heterodera glycines Ichinohe, 1952) was first described in 1915, in Japan, and detected in the United States in 1954. The first identification of this pathogen in Brazil occurred in the crop year 1991/92 (Lima et al., 1992; Lordello et al., 1992; Monteiro \& Morais, 1992) and now it is found in the Brazilian ten largest soybean producer states (MG, MS, MT, GO, SP, PR, RS, BA, TO and MA) (Dias et al., 2010).

A series of factors can affect $H$. glycines populations and even its life cycle, including inoculum density (Todd et al., 2003). Increases in $H$. glycines initial density oftentimes result in female increase in soybean root system. Brito et al. (1999) evaluated seven $H$. glycines inoculum levels (0, 2,000, 4,000, 8,000, 12,000, 16,000 and 20,000 eggss/pot) in three different periods (28, 35 and 42 days after planting) and observed that the number of females in the root system tends to increase with increasing initial inoculum. Similar results were found by Rocha et al. (2008).

Increasing nematode initial population is not always followed by an increase in the number of females or in its reproduction factor. A large number of $\mathrm{J} 2$ penetrating soybean roots cannot establish syncytia in the plant vascular tissue, and do not complete their life cycle. Moreover, resistant and susceptible cultivars present different behavior when subjected to greater or smaller inoculum pressure (Koenning, 2000).

Wang et al. (1998), evaluating the effect of different inoculum densities (100, 1,000, 4,000 and 10,000 egges and $\mathrm{J} 2$ per pot) on the determination of $H$. glycines races concluded that concentrations above 4,000 reduced the number of females in the root system of the susceptible cultivar Lee 74. Asmus and Ferraz (2002), testing six $H$. 
glycines inoculum density $(0,1,200,3,600,10,800,32,400$ and 97,200 J2/pot), observed that increasing initial population promoted a reduction of the reproduction factor.

Differences in the nematode parasitism can be observed among resistant cultivars dependingon the parent used as the source of resistance. Anand and Brar (1983), and Young (1984) observed this difference and suggested that, for better population management, more than one source of resistance to $H$. glycines should be used in the development of commercial cultivars. Brucker et al. (2005) observed different functions in the alleles linked to rhgl. The alleles linked to resistance genes of PI 437654 confer greater resistance than those linked to PI 88788. Thus, in areas with high population densities, cultivars derived from PI 88788 could have more female development in their root systems as a function of lower resistance stability.

Resistance and inoculum density also have great effect on $\mathrm{H}$. glycines survival rate. Colgrove and Niblack (2005) obtained low survival rates in differential PI 88788, PI 437654, PI 548402 and PI 90763, all resistant to $H$. glycines, and rates above $100 \%$ in susceptible cultivar Lee. Tood et al. (2003) observed that H. glycines population density affected both multiplication and survival rate. Survival rate decreases significantly with increasing population density while survival rates above $100 \%$ are found in low population densities.

This study evaluated whether resistance reaction to Heterodera glycines is effective on reducing nematode development, under high inoculum concentration, as well as whether such resistance reaction and increase in inoculum density affect juvenile penetration and survival rate of Heterodera glycines.

\section{Method}

Two experiments were done in greenhouse. The first one was done from March to April 2011 and the second one from December 2011 to January 2012. The experimental design was completely randomized, as a 3 (cultivars) $\times$ 4 (inoculum concentrations) factorial scheme, with 12 replications.

Four seeds of soybean cultivars BRSGO 8860RR (resistant to. glycines, race 3 and moderately resistant to race 14), BRSGO Chapadões (resistant to races 1, 2, 3, 4, 5 and 14) and BRS Valiosa RR (susceptible) were sown in 0.3-L clay pots, containing a mixture of sterilized soil and sand (1:1). After seedling emergence, these were thinned to one seedling per pot. Two days later, the seedlings were inoculated with 1,000, 2,500, 5,000 or 10,000 eggs and second stage (J2) juveniles of $H$. glycines, race 3 (HG type $0^{-}$), per pot. The pots were kept on raised border counters, immersed in moist sand during the experiments.

Plants from six replications were removed from the pots ten days after inoculation and the root systems were stained to evaluate juvenile penetration and determination of survival rate. The other six replications were harvested 20 days later to evaluate the number of females present.

Roots were stained by the technique of clarification in $\mathrm{NaOCl}$ and coloration with acid fuccin, adapted from Byrd et al. (1983). The root systems were shredded into $2-\mathrm{cm}$ pieces and imbibed for four minutes in $1.5 \%$ $\mathrm{NaOCl}$ solution. Subsequently, the fragments were drained, rinsed to remove excess sodium hypochlorite and soaked in water for 15 minutes.

Subsequently, a drop of stain was added to every $30 \mathrm{~mL}$ of roots soaked in water and the material was boiled. The stain was prepared by diluting $3.5 \mathrm{~g}$ acid fuccin in $250 \mathrm{~mL}$ acetic acid $(99.7 \%)$ and $750 \mathrm{~mL}$ distilled water. The root fragments were removed from boiling after 30 seconds, drained, let cool to avoid the formation of bubbles inside the root tissue and rinsed in tap water to remove excess dye. Subsequently, the roots were clarified in glycerin acidified with two drops of chloridric acid and boiled again. After clearing, the fragments were placed in glycerin and stored in a refrigerator until quantification. Stained roots were placed in Petri plates and the number of juveniles counted under a stereoscope (magnification of $15 \times$ ).

The number of females was determined in the plants harvested 30 days after inoculation. The root system was rinsed in tap water, over a set of 20 mesh and 60 mesh sieves overlayed. The material retained in the 20 mesh sieve was discarded, while that of the 60 mesh was poured over screen lined with filter paper (Andrade et al., 1995), and taken to the stereoscope (magnification of $15 \times$ ) to count the number of females.

Ten females were arbitrarily taken after quantification and burst over a set of 100 mesh and 400 mesh sieves. The suspension containing the eggs retained in the 400 mesh sieve was place in a $50-\mathrm{mL}$ beaker, and homogenized. The number of eggs present in a 1-mL aliquot was determined in a light microscope (magnification 50×), with the aid of Peters' chamber, in three repetitions. The root system of the plants was weighed (fresh weight) after nematode extraction. 
The number of juveniles in the stained roots and the number of females present in the root systems were used to determine the survival rate, which is given by the proportion between the number of females and the number of juveniles.

The data were subjected to analysis of variance, using SISVAR (Ferreira, 2000), and the averages compared by the Tukey test at 5\% probability. Whenever significant differences were observed among the inoculum concentrations, regression analyses were done using SISVAR (Ferreira, 2000). All data were transformed by $\sqrt{x+1}$ before analysis.

\section{Results and Discussion}

Significant interaction was found in the number of females in the roots $(\mathrm{P}<0.05)$ among soybean cultivars and inoculum density in the first experiment. The number of females observed in the roots of susceptible cultivar BRS Valiosa RR was greater than that found in the resistant cultivars BRSGO 8860RR and BRSGO Chapadões, in all inoculum density (Table 1).

Table 1. Average number of females and eggs per female in soybean cultivars BRS Valiosa RR, BRSGO 8860RR and BRSGO Chapadões subjected to increasing Heterodera glycines inoculum densities. Goiânia - GO

\begin{tabular}{|c|c|c|c|c|c|c|}
\hline \multicolumn{7}{|c|}{ Experiment 1 (March-April/2011) } \\
\hline \multirow{3}{*}{$\begin{array}{l}\text { Inoculum Densities } \\
\text { (Eggs and } \mathrm{J} 2 \text { ) }\end{array}$} & \multicolumn{3}{|c|}{ Females* } & \multicolumn{3}{|c|}{ Eggs/Females } \\
\hline & BRS & BRSGO & BRSGO & BRS & BRSGO & BRSGO \\
\hline & Valiosa RR & 8860RR & Chapadões & Valiosa RR & $8860 \mathrm{RR}$ & Chapadões \\
\hline 1000 & $17.33 \quad \mathrm{~B} * *$ & $0.67 \mathrm{~A}$ & $0.00 \mathrm{~A}$ & 46.15 & 50.67 & 0.00 \\
\hline 2500 & $42.17 \quad \mathrm{~B}$ & $4.17 \mathrm{~A}$ & $0.00 \mathrm{~A}$ & 50.26 & 23.60 & 0.00 \\
\hline 5000 & $61.00 \quad \mathrm{~B}$ & $3.33 \mathrm{~A}$ & $0.17 \mathrm{~A}$ & 42.42 & 23.04 & 8.00 \\
\hline 10000 & $159.67 \mathrm{~B}$ & $11.67 \mathrm{~A}$ & $0.17 \mathrm{~A}$ & 54.05 & 23.30 & 8.50 \\
\hline Média & 70.04 & 4.96 & 0.08 & $48.22 \mathrm{C}$ & $30.15 \mathrm{~B}$ & 4.13 \\
\hline $\mathrm{CV}(\%)$ & 49.96 & & & 46.39 & & \\
\hline \multicolumn{7}{|c|}{ Experiment 2 (December/2011-January/2012) } \\
\hline 1000 & 19.33 & 1.67 & 0.00 & 45.02 & 12.46 & 0.00 \\
\hline 2500 & 59.67 & 6.67 & 0.00 & 40.45 & 12.48 & 0.00 \\
\hline 5000 & 64.50 & 9.17 & 0.00 & 27.63 & 17.61 & 0.00 \\
\hline 10000 & 89.83 & 8.67 & 0.00 & 39.76 & 9.19 & 0.00 \\
\hline Média & 58.33 & 9.88 & $0.00 \mathrm{~A}$ & $38.21 \mathrm{C}$ & $12.93 \mathrm{~B}$ & $0.00 \mathrm{~A}$ \\
\hline CV (\%) & 55.65 & & & 39.28 & & \\
\hline
\end{tabular}

Note. $*$ Data transformed into $\sqrt{x+1}$, for statistical analysis.

** Averages followed by the letter in the rows do not differ significantly by the Tukey test at $5 \%$ probability.

No significant interaction was found in the second experiment; however, differences were found for cultivar and for inoculum density $(\mathrm{P}<0.05)$. The susceptible cultivar BRS Valiosa RR presented greater number of females in the roots than cultivar BRSGO 8860RR. Female development in resistant cultivar BRSGO 8860RR was different from resistant cultivar BRSGO Chapadões, in which female formation was practically nil (Table 1). The difference in parasitism between the two resistant cultivars probably is due to of its source of resistance. The source of resistance to $H$. glycines in BRSGO Chapadões comes from PI 437654, while that of cultivar BRSGO 8860RR comes from PI 88788, which provide more unstable resistance (Dias et al., 2007).

Brucker et al. (2005) observed that PI 88788 and PI 437654 each have a different functional resistance allele against $H$. glycines in gene $r h g 1$ or near it, resulting in different responses to the parasitism of this nematode. The alleles linked to resistance genes of PI 437654 confer greater resistance than those linked to PI 88788. Due to this difference, development of $H$. glycines is observed in the roots of cultivars originated from PI 88788, although in smaller numbers than that presented by susceptible cultivars (Dongo \& Opperman, 1997; Li et al., 2004).

The number of females per root system increased, in the first experiment as a function of initial inoculum in the susceptible cultivar BRS Valiosa RR and in the resistant cultivar BRSGO 8860RR (P < 0.05) (Figure 1A). Similar results were obtained for the susceptible cultivar BRS Valiosa RR, in the second experiment (Figure 1B). 
Such an increase in the number of females is expected, especially in the susceptible cultivar, since increasing the density of $\mathrm{J} 2$ increases the infection rate and, since this cultivar has no resistance genes, nematode development is not halted. Thus, increasing $H$. glycines initial inoculum tends to increase the number of females present in the root system of soybean cultivars susceptible to the nematode (Koenning, 2000).

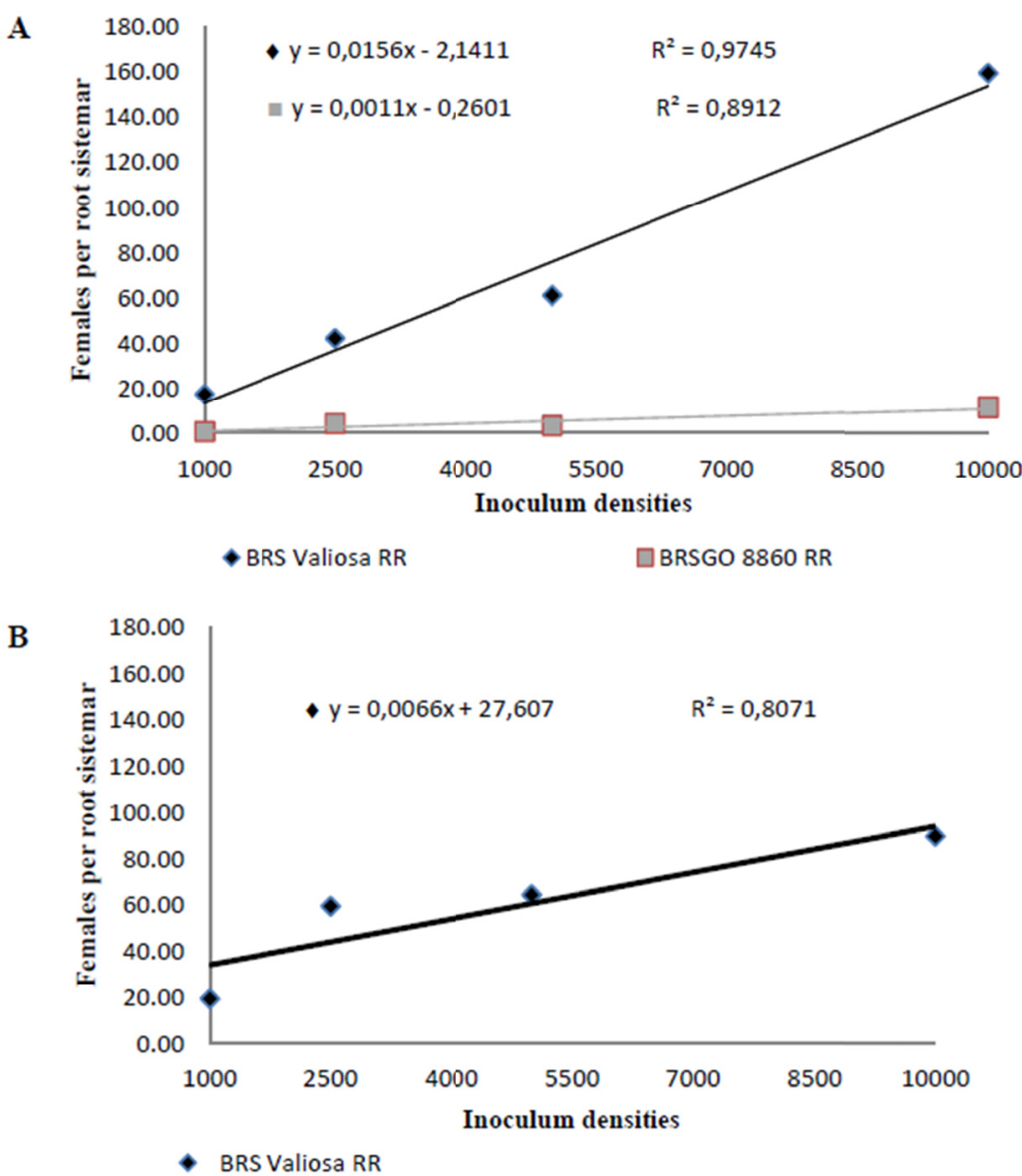

Figure 1. Average number of females per root system of soybean cultivars subjected to increasing Heterodera glycines inoculum concentrations. Figure A: experiment done from March to April 2011; Figure B: experiment done from December 2011 to January 2012, Goiânia-GO

These results corroborate those of Brito et al. (1999), who determined that increasing the number of $H$. glycines eggs inoculated in the root system of susceptible soybean cultivar FT-Cristalina is followed by an increase in the number of females. However, it is important to note that nematode increasing parasitism occurs to a certain level. Whenever density is too high the competition for feeding sites increases, resulting in a reduction of nematodes in the root system. Wang et al. (1998) observed that in inoculum densities above 4,000 H. glycines eggs and J2 the number of females per root system in susceptible cultivar Lee 74 decreased in relation to lower concentrations. Asmus and Ferraz (2002) concluded that increased initial inoculum concentrations of $H$. glycines reduce the reproduction factor of the nematode.

Inoculum density increases in resistant cultivars may not cause increase in the number of females. Such an increase was observed only for cultivar BRSGO 8860RR, in experiment 1 (Figure 1A), but not for experiment 2. Nematode parasitism in Cultivar BRSGO Chapadões, also resistant to the cyst nematode, was not affected by inoculum density in any experiment. These results indicate that resistance of cultivar BRSGO 8860RR is affected under high inoculum concentration, while that of cultivar BRSGO Chapadões is not. This difference between resistant cultivars is due to the sources of resistance used in obtaining them. Since $H$. glycines has great genetic variability, resistance sources often do not extend to all individuals in a population (Anand \& Brar, 1983; Young, 1992). Greater female development in the root system of cultivar BRSGO 8860RR probably occurred due to lower resistance stability conferred by PI 88788 (Dongo \& Opperman, 1997; Li et al., 2004; Brucker et al., 
2005; Faghihi et al., 2007). Therefore, the use of more than one resistance source is suggested for breeding new cultivars, increasing the resistance spectrum against H. glycines (Anand \& Brar, 1983; Young, 1984). Similarly, the farmers should use cultivars with different resistance sources.

Resistance reaction of cultivars is not affected by increased inoculum concentrations. Even under high $H$. glycines inoculum concentrations, resistant cultivars BRSGO 8860RR and BRSGO Chapadões, maintain smaller number of females per root system in comparison to the susceptible cultivar BRS Valiosa RR (Table 1). These results indicate that using genetic resistance would be effective for reducing nematode population even under high inoculum densities. However, the use of resistant cultivars alone, as the only management strategy for the cyst nematode may lead to a selection of individuals capable of parasitizing these cultivars. Successive croppings could increase the number of these individuals and the loss of resistance (Dias et al., 1998).

The number of eggs per female was affected only by cultivars and, in both experiments, the susceptible cultivar, BRS Valiosa RR, had greater number of egss per female, and were significantly different from the resistant cultivars BRSGO 8860RR and BRSGO Chapadões $(\mathrm{P}<0.05)$ (Table 1). It is important to highlight that egg quantification in the susceptible cultivar was very low, considering that in Brazilian conditions approximately 100 to 250 eggs per female are expected (Embrapa, 2011). However, even with such low numbers, differences were observed among resistant and susceptible cultivars.

Lower numbers of eggs per female in the resistant cultivars was expected since they have the resistance gene $r g h$ 1 against $H$. glycines, affecting growth, development and fertility of females ( $\mathrm{Li}$ et al., 2004). Also, differences in the number of eggs per female were observed between the two resistant cultivars $(P<0.05)$. This occurred because cultivar BRSGO 8860RR allowed female development, while the number of females in cultivar BRSGO Chapadões was practically nil (Table 1).

Interaction among cultivars and inoculum concentrations was observed for nematode penetration in the first experiment 1 , while only the effect of inoculum density was observed in the secondo experiment $(\mathrm{P}<0.05)$ (Table 2).

Table 2. Heterodera glycines penetration and survival rate in soybean cultivars BRS Valiosa RR, BRSGO 8860RR and BRSGO Chapadões subjected to increasing H. glycines inoculum densities. Goiânia, GO

\begin{tabular}{|c|c|c|c|c|c|c|c|c|}
\hline \multicolumn{9}{|c|}{ Experiment 1 (March-April/2011) } \\
\hline \multirow{3}{*}{$\begin{array}{l}\text { Inoculum Densities } \\
\text { (Eggs and J2) }\end{array}$} & \multicolumn{5}{|c|}{ Penetration* } & \multicolumn{3}{|c|}{ Survival Rate } \\
\hline & \multirow{2}{*}{\multicolumn{2}{|c|}{$\begin{array}{l}\text { BRS } \\
\text { Valiosa RR }\end{array}$}} & \multirow{2}{*}{\multicolumn{2}{|c|}{$\begin{array}{l}\text { BRSGO } \\
8860 \mathrm{RR} \\
\end{array}$}} & \multirow{2}{*}{$\begin{array}{l}\text { BRSGO } \\
\text { Chapadões }\end{array}$} & \multirow{2}{*}{$\begin{array}{l}\text { BRS } \\
\text { Valiosa RR }\end{array}$} & \multirow{2}{*}{$\begin{array}{l}\text { BRSGO } \\
\text { 8860RR }\end{array}$} & \multirow{2}{*}{$\begin{array}{l}\text { BRSGO } \\
\text { Chapadões }\end{array}$} \\
\hline & & & & & & & & \\
\hline 1000 & 23.00 & $\mathrm{~A}^{* *}$ & 33.00 & $\mathrm{~A}$ & $16.50 \quad \mathrm{~A}$ & 134.27 & 3.61 & 0.00 \\
\hline 2500 & 61.33 & A & 45.33 & A & 24.17 & 85.70 & 12.41 & 0.00 \\
\hline 5000 & 157.83 & A & 150.33 & A & 91.50 & 38.13 & 2.94 & 0.28 \\
\hline 10000 & 433.67 & $\mathrm{~B}$ & 175.17 & A & $193.50 \mathrm{~A}$ & 43.05 & 9.54 & 0.49 \\
\hline Average & 168.96 & & 100.96 & & 81.42 & 75.61 & 7.12 & 0.19 \\
\hline CV (\%) & 31.13 & & & & & 60.32 & & \\
\hline \multicolumn{9}{|c|}{ Experiment 2 (December/2011-January/2012) } \\
\hline 1000 & 36.17 & & 53.67 & & 58.67 & 80.71 & 26.13 & 0.00 \\
\hline 2500 & 66.50 & & 96.50 & & 91.17 & 106.89 & 8.34 & 0.00 \\
\hline 5000 & 91.00 & & 229.67 & & 199.17 & 121.90 & 3.43 & 0.00 \\
\hline 10000 & 157.67 & & 149.50 & & 125.17 & 147.14 & 6.01 & 0.00 \\
\hline Average & 87.83 & & 132.33 & & 118.54 & 114.16 & $12.92 \mathrm{~A}$ & 0.00 \\
\hline CV $(\%)$ & 39.22 & & & & & 78.78 & & \\
\hline
\end{tabular}

Note. $*$ Data transformed into $\sqrt{x+1}$ for statistical analysis.

** Averages followed by the letter in the rows do not differ significantly by the Tukey test at $5 \%$ probability.

Differences between susceptible and resistant cultivars were observed in the first experiment, for the greatest inoculum densities (10,000 eggs and $\mathrm{J} 2$ per plant). There was greater penetration of $\mathrm{H}$. glycines $\mathrm{J} 2$ in the root system of cultivar BRS Valiosa RR than in the resistant cultivars. However, no penetration differences were observed for all other densities in the different cultivars. This could be explained because resistance reaction to $H$. 
glycines occurs after nematode penetration. Heterodera glycines juveniles penetrate normally in resistant cultivars but are incapable of establishing feeding sites due to the deterioration of syncytium shortly after formation, resulting in nematode death inside the root tissue (Kim et al., 1987; Kim \& Riggs, 1992). Since this resistance reaction does not occur immediately after penetration, early evaluations, such as the one $10 \mathrm{DAI}$, may indicate a large number of juveniles in the roots.

Penetration in experiment 1 increased linearly as the inoculum density increased for all three cultivars, although the number were smaller in the resistant cultivars than in the susceptible one (Figure 2A). A linear increase was observed in experiment 2 for cultivar BRS Valiosa RR (Figure 2B). In contrast, a quadratic effect was observed for cultivar BRSGO 8860RR, increasing juvenile penetration until 6,741 eggs and J2 per plant, and decreasing afterward. Such decrease could be due to competition among the infecting forms of $\mathrm{H}$. glycines for penetration sites and the subsequent establishment of feeding sites. Thus, as the inoculum density increases, so does the competition among individuals, which could result in a reduction of the reproduction factor of the nematode (Asmus \& Ferraz, 2002).
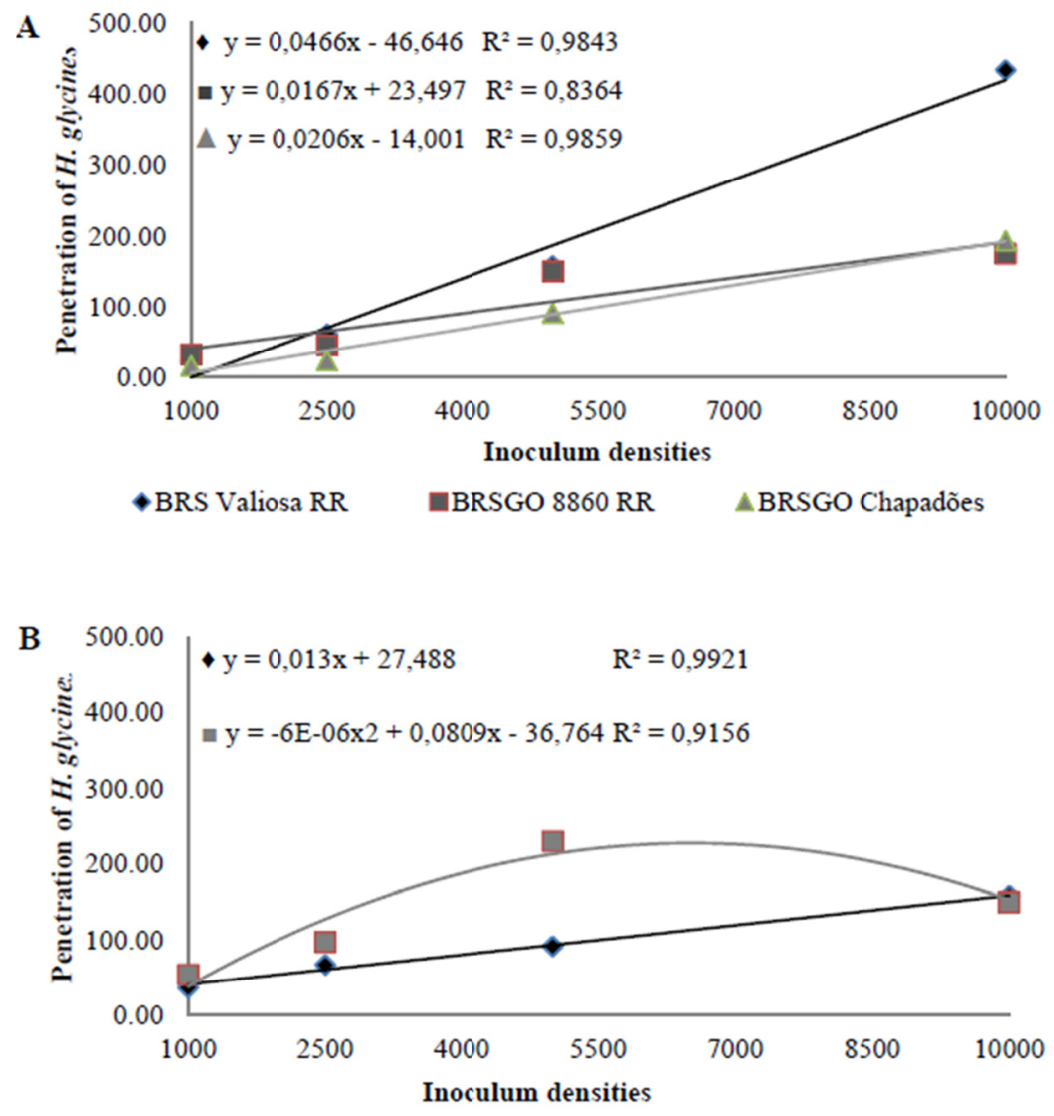

$\bullet$ BRS Valiosa RR

ERRSGO $8860 \mathrm{RR}$

Figure 2. Heterodera glycines juvenile penetration in the root system of soybean cultivars subjected to increasing H. glycines inoculum concentrations. Figure A: experiment done from March to April 2011; Figure B: experiment done from December 2011 to January 2012, Goiânia-GO

Survival rate of the nematode was affected only by the soybean cultivars $(\mathrm{P}<0.05)$ (Table 2). Survival rate in the susceptible cultivar BRS Valiosa RR was greater than that observed in the resistant cultivars for both experiments (Table 2). A lower survival rate was expected in soybean cultivars resistant since even with penetration, many nematodes can not complete its cycle. Some juveniles may have their development halted shortly after syncytium establishment (Kim et al., 1987; Kim \& Riggs, 1992), while others may reach stages J3, $\mathrm{J} 4$ or even the adulthood, depending on the resistance of the cultivar. As mentioned previously, cultivar BRSGO 8860RR, with resistance source derived from PI 88788, allows some development of adult females in its roots, although in smaller numbers than in susceptible cultivar (Table 1). 
Survival rates in the resistant cultivar varied from $0 \%$ to $26.13 \%$ (Table 2) and were near the values found by Colgrove and Niblack (2005) for the differentials PI 88788, PI 437654, PI 548402 and PI 90763, all resistant to H. glycines. In the susceptible cultivar, BRS Valiosa RR, such rates varied from $43.05 \%$ to $147.14 \%$. Evans and Fox (1977), and Colgrove and Niblack (2005) found rates varying from 22.3 to $33 \%$ and 66.6 to $111.1 \%$, respectively, for susceptible cultivar Lee, demonstrating the great variation in survival rates on susceptible cultivars, and that this rate can be above $100 \%$. Tood et al. (2003) observed that $H$. glycines population density directly affected survival rate of the nematode and that this rate tends to decrease sharply with increasing population densities.

\section{Conclusion}

Increasing Heterodera glycines initial inoculum density increased final population of the nematode in the susceptible cultivar, and the resistance reaction of soybean cultivars is not affected by high inoculum concentration.

Penetration of $H$. glycines $\mathrm{J} 2$ in the roots increases with increasing inoculum concentration, regardless of resistance or susceptibility of the cultivar, and nematode survival rate is greater in susceptible cultivars.

\section{References}

Alston, D. G., \& Schimtt, D. P. (1988). Development of Heterodera glycines life stages as influenced by temperature. Journal of Nematology, 20, 366-372.

Anand, S. C., \& Brar, G. S. (1983). Response of soybean lines to differentially selected cultures of soybean cyst nematode Heterodera glycines Ichinohe. Journal of Nematology, 15, 120-123.

Andrade, P. J. M., Asmus, G. L., \& Silva, J. F. V. (1995). Um novo sistema para deteç̧ão e contagem de cistos de Heterodera glycines recuperados de amostras de solo. Fitopatologia Brasileira, 20, 358.

Asmus, G. L., \& Ferraz, L. C. (2002). Effect of population densities of Heterodera glycines race 3 on leaf area, photosynthesis and yield of soybean. Fitopatologia Brasileira, 27, 273-278. https://doi.org/10.1590/S010041582002000300006

Brito, C. H., Sediyama, T., Pozza, E. A., \& Dias, W. P. (1999). Níveis de inóculo e época para avaliação de populações de Heterodera glycines Ichinohe em soja. Ciência e Agrotecnologia, 23, 836-840.

Brucker, E., Carlson, S., Wright, E., Niblack, T., \& Diers, B. (2005). Rhg1 alleles from soybean PI 437654 and PI 88788 respond differentially to isolates of Heterodera glycines in the greenhouse. Theoretical and Applied Genetics, 111, 44-49. https://doi.org/10.1007/s00122-005-1970-3

Byrd, D. W., Kirpatrick, T., \& Barker, K. R. (1983). An improved technique for clearing and staining plant tissue for detection of nematodes. Journal of Nematology, 15, 142-143.

Colgrove, A. L., \& Niblack, T. L. (2005). The effect of resistant soybean on male and female development and adult sex ratios of Heterodera glycines. Journal of Nematology, 37, 161-167.

Dias, W. P., Garcia, A., Silva, J. F. V., \& Carneiro, G. E. S. (2010). Nematoides em soja: Identificação e controle (pp. 1-8). Comunicado Técnico, Embrapa Soja.

Dias, W. P., Silva, J. F. V., Garcia, A., Carneiro, G. E. S. (2007). Nematoides de importância para a soja no Brasil. Boletim de Pesquisa de Soja 2007 (pp. 173-184). Fundação, MT.

Dias, W. P., Silva, J. F. V., Kiihl, R. A. S., Hiromoto, D. M., \& Abdelnoor, R. V. (1998). Quebra da resistência da cv. Hartwing por população de campo do nematoide de cisto da soja (Heterodera glycines). Pesquisa Agropecuária Brasileira, 33, 971-974.

Dongo K., \& Opperman, C. H. (1997). Genetic analysis of parasitism in the soybean cyst nematode Heterodera glycines. Genetics, 146, 1311-1318.

Embrapa (Empresa Brasileira de Pesquisa Agropecuária). (2011). Tecnologias de Produção de Soja Região Central do Brasil 2012 e 2013. Sistemas de Produção 15, Embrapa Soja, 262. Londrina, PR.

Evans, D. M., \& Fox, J. A. (1977). The sex ratio of Heterodera glycines at low population densities. Journal of Nematology, 9, 207-210.

Faghihi, J., Ferris, V., Donald, P., Noel, G., \& Welacky, T. (2008). Changes in resistance of PI88788 to field populations of soybean cyst nematode (SCN) (p. 235). The 5th Internetional Congress of Nematology.

Ferreira, D. F. (2000). Análises estatísticas por meio do Sisvar para Windows versão 4.0 (pp. 255-258). Reunião Anual da Região Brasileira da Sociedade Internacional de Biometria. 
Heatherly, L. G., Young, L. D., Epps, J. M., \& Hartwing, E. E. (1992). Effect of upper-profile soil water potential on numbers of cysts of Heterodera glycines on soybeans. Crop Science, 22, 833-835. https://doi.org/ 10.2135/cropsci1982.0011183X002200040031x

Johnson, A. B., Kim, K. S., Riggs, R. D., \& Scott, H. D. (1993). Locations of Heterodera glycines induced syncytia in soybean as affected soil water regimes. Journal of Nematology, 25, 422-426.

Kim, K. S., \& Riggs, R. D. (1992). Cytopathological reactions of resistant soybean plants to nematode invasion. In R. D. Riggs, et al. (Eds.), Biology and management of the soybean cyst nematode (pp. 157-268). St. Paul, APS Press.

Kim, Y. H., Riggs, R. D., \& Kim, K. S. (1987). Structural changes associated with resistance os soybean to Heterodera glycines. Journal of Nematology, 19, 177-187.

Koenning, S. R. (2000). Density-dependent yield of Heterodera glycines resistant and susceptible cultivars. Journal of Nematology, 32, 502-507.

Li, Y., Chen, S., \& Young, N. D. (2004). Effect of the $r g h 1$ gene on penetration, development and reproduction of Heterodera glycines race 3. Nematology, 6, 729-736. https://doi.org/10.1163/1568541042843522

Lima, R. D., Ferraz, S., \& Santos, J. M. (1992). Ocorrência de Heterodera sp. em soja no Triangulo Mineiro (Vol. 16, No. 81). Sociedade Brasileira de Nematologia - Congresso Brasileiro de Nematologia.

Lordello, A. I., Lordello, R. R. A., \& Quaggio, J. A. (1992). Heterodra sp. reduz produção de soja no Brasil (Vol. 16, No. 81). Sociedade Brasileira de Nematologia — Congresso Brasileiro de Nematologia.

Monteiro, A. R., \& Morais, S. R. A. C. (1992). Ocorrência do nematoide de cisto da soja, Heterodera glycines, Ichinohe, 1952, prejudicando a cultura da soja no Mato Grosso do Sul (Vol. 16, p. 82). Sociedade Brasileira de Nematologia - Congresso Brasileiro de Nematologia.

Rocha, F. S., Pinheiro, J. B., Campos, H. D., \& Campos, V. P. (2008). Relação entre populações iniciais de Meloidogyne javanica e Heterodera glycines e o desenvolvimento do sistema radicular da soja. Nematologia Brasileira, 32, 161-166.

Ross, J. P. (1963). Effect of soil temperature on development of Heterodera glycines in soybean roots. Phytopathology, 54, 815-818.

Tood, T. C., Long, J. H., Oakley, T. R. (2003). Density-dependent multiplication and survival rates in Heterodera glycines. Journal of Nematology, 35, 98-103.

Wang, S., Riggs, R. D., \& Crippen, D. (1998). Soil infestation density the results of Heterodera glycines race tests. Journal of Nematology, 30, 553-562.

Young, L. D. (1984). Changes in the reproduction of Heterodera glycines on different lines of Glycine max. Journal of Nematology, 16, 304-309.

Young, L. D. (1992). Epiphytology and life cycle. In R. D. Riggs, et al. (Eds.), Biology and management of the soybean cyst nematode (pp. 27-36). St. Paul, APS Press.

\section{Copyrights}

Copyright for this article is retained by the author(s), with first publication rights granted to the journal.

This is an open-access article distributed under the terms and conditions of the Creative Commons Attribution license (http://creativecommons.org/licenses/by/4.0/). 